\title{
Identification and Expression of Some Plant Cell Wall-Degrading Enzymes Present in Three Ontogenetics Stages of Thecaphora frezii, a Peanut (Arachis hypogaea L.) Pathogenic Fungus
}

\author{
Néstor Walter Soria ${ }^{1 *}$, Ana Cristina Figueroa ${ }^{2}$, María Soledad Díaz², Valeria Roxana Alasino ${ }^{2,3}$, \\ Pablo Yang1, Dante Miguel Beltramo1,2,3* \\ ${ }^{1}$ Cátedra de Biotecnología, Facultad de Ciencias Químicas, Unidad Asociada al CONICET: Área de Cs. Agrarias, Ingeniería, Cs. \\ Biológicas, Universidad Católica de Córdoba, Córdoba, Argentina \\ ${ }^{2}$ Centro de Excelencia en Productos y Procesos de Córdoba-CEPROCOR, Santa María de Punilla, Córdoba, Argentina \\ ${ }^{3}$ CONICET, Santa María de Punilla, Córdoba, Argentina \\ Email: *nestorwsoria@gmail.com, *dbeltramo@yahoo.com.ar
}

How to cite this paper: Soria, N.W., Figueroa, A.C., Díaz, M.S., Alasino, V.R., Yang, P. and Beltramo, D.M. (2022) Identification and Expression of Some Plant Cell Wall-Degrading Enzymes Present in Three Ontogenetics Stages of Thecaphora frezii, a Peanut (Arachis hypogaea L.) Pathogenic Fungus. American Journal of Plant Sciences, $13,1-22$.

https://doi.org/10.4236/ajps.2022.131001

Received: December 8, 2021

Accepted: January 10, 2022

Published: January 13, 2022

Copyright $\odot 2022$ by author(s) and Scientific Research Publishing Inc. This work is licensed under the Creative Commons Attribution International License (CC BY 4.0).

http://creativecommons.org/licenses/by/4.0/ (c) (i) Open Access

\begin{abstract}
Peanuts can be affected by the presence of pathogenic microorganisms. The fungus Thecaphora frezii ( $T$. frezii), which belongs to the taxonomic class Ustilaginomycetes, is the causal agent of the disease known as "peanut smut". The life cycle of this fungus includes three stages, namely teliospores, basidiospores and hyphae. In the hyphae stage, infection occurs in the peanut plant, which requires the involvement of some enzymes secreted by the fungus. These include the Plant Cell Wall-Degrading Enzymes (PCWDEs), which degrade various polysaccharides. This study aimed to identify the presence of transcript for enzymes belonging to the PCWDEs from three stages of $T$. frezii. For this, total RNA was extracted from the three ontogenetic stages of $T$. frezii. These samples were analyzed using an RNA-Seq approach and some transcripts were quantified using Real Time PCR. The analysis of the data provided by the RNA-Seq of the three $T$. frezii stages, it was possible to identify some transcripts that could encode enzymes compatible with polysaccharides degradation that are part of the plant cell wall. In $T$. frezii transcriptome, 40 deduced proteins would be enzymes with functions of PCWDEs were identified. They were divided into 27 glycoside hydrolases; two polysaccharide lyases; three carbohydrate esterases and eight enzymes with auxiliary activities. In addition, the fungal SNF1 gene was identified whose activity could be affected by high glucose level, and indirectly influence
\end{abstract}


the levels of some PCWDEs. The analysis of the PCWDEs could help to understand part of the fungal infection process and possibly find substances that can control its development.

\section{Keywords}

Carbohydrate-Degrading Enzymes, Phytopathogenic Fungi, Smut Fungi, Transcriptome, Thecaphora frezii

\section{Introduction}

At present, it is known that there are a large number of pathogenic microorganisms that affect plants, including fungi, some of which have an impact on crops of various plantations [1] [2]. One mechanism through which these microorganisms affect target plants is the secretion of enzymes that attack their cell walls. This wall is a great barrier that limits the action of microorganisms, and these enzymes are part of the so-called Plant Cell Wall-Degrading Enzymes (PCWDEs) [3], which are responsible for degrading several polysaccharides (cellulose, hemicellulose and pectins) and glycoproteins [4]. The complex nature of cellulose, hemicellulose, pectins, glycoproteins and their interactions within the cell wall make up a diverse structure and constitute an effective barrier against plant pathogens [5]. The composition of this cell wall may change based on the stage of development, growth and response of the plant to external conditions [6]. In nature, there are a large number of enzymes that make up a complex system that aims at degrading the carbohydrates that are components of the plant cell wall, which make this wall susceptible to attacks by numerous microorganisms. Among them, a family of proteins has been classified as demonstrating reasons that confer catalytic activity against carbohydrates to enzymes called Carbohydrate-Active enZyme (CAZyme) [7]. Within this wide enzymatic arsenal, there are the Glycoside Hydrolases (GH), Polysaccharide Lyases (PL), Carbohydrate Esterases (CE), enzymes with Auxiliary Activities (AA) and Non-catalytic Carbohydrate Binding Modules (CBM) [8] [9] [10]. The identification and comparison of these fungal CAZymes that have different nutritional modes or infection mechanisms can provide information for a better understanding of their lifestyle and infection patterns [11].

Peanuts (Arachis hypogaea L.) is one of the most important legume crops in the world, native to South America, distributed in Brazil, Paraguay, Bolivia, Argentina and Uruguay [12]. In Argentina, crops are mainly found in the province of Córdoba, with a contribution of $92 \%$ of the national primary production [13]. During the growing cycle, peanuts are frequently attacked by fungal diseases, especially, those that develop in the soil during the fruit formation stage, during harvest and in the drying and storage phases of the grain [14] [15] [16]. Some of the fungi responsible for diseases in peanuts include the genera Aspergillus, Penicillum, Sclerotinia, Fusarium, Rhizopus and Thecaphora [17] [18] [19]. One of 
these diseases is called "peanut smut", which is caused by Thecaphora frezii ( $T$. frezii), a biotrophic fungus (it infects its host without causing cell death to complete its life cycle) and single peanut host, which produces numerous yearly losses, with a higher incidence in the southern part of the province of Córdoba. The fungus was, first, detected by Carranza and Lindquist in wild diploid peanut germplasm from Aquidauana, Brazil [20], and, in Argentina, in the 1994/95 campaign, while its prevalence, incidence and severity have been increasing in the last 10 years, expanding, in addition, to other provinces of Argentina [21] [22]. There are three ontogenetic stages described for T. frezii life cycle: teliospores, which represent the resistance structures; basidiospores, formed after the germination of teliospores; and hyphae, formed by the fusion of compatible germinating basidiospores. These hyphae infect the stalks peg when it enters the ground by penetrating from the outside and by passing through the tissues until they reach the seeds [23]. Inside the plant, it closes its cycle by forming teliospores again, producing deformation and hypertrophy of the fruits, with the ability to affect only one seed or the entire fruit, transforming it into a carbonaceous mass of reddish-brown spores. Teliospores have poor germination in vitro, but Cazón and collaborators [24], achieved their germination in PDA with the addition of grain extract. However, by placing a large number of spores our team was able to obtain their germination in PDA [25]. Likewise, it was possible to obtain basidiospores in vitro, employing a poor-nutrient media [25]. To obtain basidiospores, their growth can be induced depending on the culture medium used, a nutritional fast, heat shock and the $\mathrm{pH}$ of the medium that are factors that induce the formation of basidiospores [26] [27].

The aim of this work was to identify the presence in T. frezii, and in its three stages; transcript for enzymes belonging to the PCWDE group with the potential to degrade the polysaccharides presents in the cell wall of the peanut plant. In turn, the relative mRNA quantification was done (the quantification that is carried out is indicative since it is done from an "in vitro" culture for basidiospores and hyphae, and for teliospores from infected pods). Despite this, the results could contribute to understanding whether there is a correlation between the level of expression and the infective process, since an increase in expression in the basidiospore stage, but more particularly in the hyphae stage, would be strongly suggestive of this action [28]. This phenomenon is also noted in other fungi, Ustilago maydis (U. maydis) and Magnaporthe oryzae, which infect maize and rice plants, respectively. In both cases, an increased expression of genes coding for cellulases, hemicellulases and pectate lyases was observed [29] [30]. Meanwhile, some organisms can adapt to their environment and synthesize specific enzymes according to the carbon source that is available. The enzyme function that could be regulated by the glucose levels is the non-fermentative sucrose protein kinase serine threonine (Snf1) [31] [32]. Snf1 also has roles in several cellular mechanisms [33]. We try to identify at least partially the Snf1 transcript in $T$. frezii and its expression levels which could condition the expression levels of some PCWDEs. 


\section{Materials and Methods}

\subsection{Collection, Isolation and Cultivation of Thecaphora frezii}

Teliospores of $T$. frezii were obtained from peanut pods showing symptoms of disease (hypertrophy, because we have not been able to grow teliospores in culture without changing their ontogenetic stage). The pods were superficially disinfected with $0.5 \% \mathrm{NaOCl}(\mathrm{v} / \mathrm{v})$, plated on potato-dextrose agar (Britannia PDA) and incubated at $26^{\circ} \mathrm{C}$ in the dark until germination. Once the hyphae had developed, they were multiplied in potato broth (Neogen) for 24 hours while stirring at $26^{\circ} \mathrm{C}$. To obtain the basidiospores, an inoculum of hyphae from the liquid culture was transferred to agar/water $(1.5 \% \mathrm{w} / \mathrm{v})$ and incubated for 10 days at $26^{\circ} \mathrm{C}$ in the dark until the formation of the basidiospores, which was corroborated by optical microscopy (Figure 1).

\subsection{RNA Extraction}

Total RNA from the three stages of $T$. frezii (three independent cultivars were pooled for each stage) was extracted with TRIzol (Invitrogen, California) according to the manufacturer's recommendations. gDNA was removed by on-column digestion with DNase (Qiagen, Germany) at twice the manufacturer's recommended concentration. Possible RNA degradation and impurities were monitored on a $1.5 \%(\mathrm{w} / \mathrm{v})$ agarose gel and RNA purity was confirmed using NanoPhotometer spectrophotometer (Implen, California). RNA concentration was measured using the Qubit RNA assay kit and the Qubit Fluorometer 2.0 (Life Technologies, California).

\subsection{Library Preparation and RNA-Seq}

The cDNA library was prepared using the RNA of the three stages of $T$. frezii. They were performed using the NEB Next Ultra RNA kit for Illumina ( $\mathrm{Ne}$ braska) according to the manufacturer's instructions.

\subsection{RNA-Seq Data Analysis}

After cluster generation, the cDNA libraries were sequenced on Illumina HiSeq 1500 to obtain $2 \times 150 \mathrm{bp}$ pair-end reads at the service facilities of INDEAR

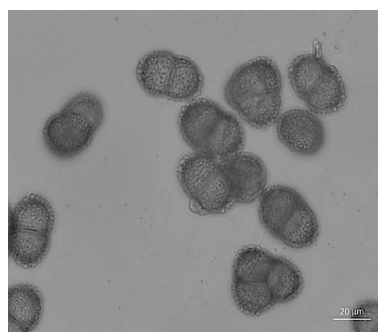

(A)

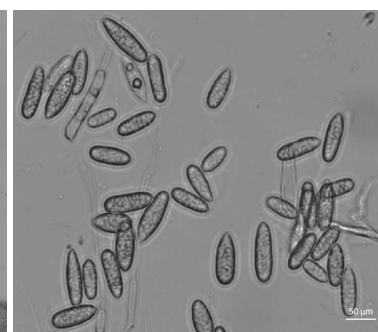

(B)

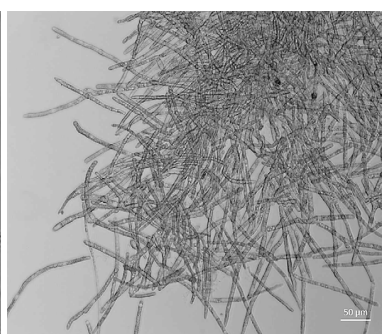

(C)

Figure 1. Optical microscopy images from the different $T$. frezii ontogenetic stages: (A) Teliospores, (B) Basidiospores and (C) Hyphae (600x). 
(Rosario, Argentina). Briefly, a de novo transcriptome was assembled with all reads, then gene expression in each condition was calculated using counts per million (CPM) of reads. RNA-Seq read quality was checked using FastQC software (http://www.bioinformatics.babraham.ac.uk/projects/fastqc/). Reads of the three ontogenetic stages of the fungus were performed and compared (basidiospores, hyphae and teliospores).

Fold change (FC) and statistical significance for all comparisons was determined by General Linear Model statistics using the EdgeR package 3.4.2 from Bioconductor [34] in the R environment (3.0.2, [35]).

\subsection{Identification of $T$. frezii PCWDEs}

From the analysis of the RNA-Seq data (mRNA), the sequences of the T. frezii proteins were deduced, which were screened to detect the presence of active carbohydrate modules using the Carbohydrate-active enzyme ANnotation (dbCAN, [36] [37]). The annotation of CAZyme modules by this program uses E-value, alignment length and coverage, with an E-value of $<1 \mathrm{e}-5$ for alignments of $>80$ amino acids and an E-value of $<1 \mathrm{e}-3$ for alignments of $<80$ amino acids [38].

To eliminate proteins that were identified by dbCAN but were not truly CAZyme, all proteins with CAZyme motifs were examined individually using $\mathrm{My}$ Hits [39], Prosite [40] and BLASTp of non-redundant protein sequences in National Center for Biotechnology Information (NCBI) (National Center for Biotechnology Information. Available at: https://www.ncbi.nlm.nih.gov/. Accessed: 15 March 2021 [41]). Proteins, for which the alignment coverage was less than 0.5 , were also examined individually. Putative PCWDEs identified were those containing GH, PL, CE, CBM and AA modules known to be associated with the degradation of carbohydrates in the cell wall. To identify PCWDEs that may have been missed by dbCAN, additional searches, including keyword and PFAM [42] domain searches and tBLASTn analyzes [43] were performed with characterized proteins listed on the CAZy site [38] [44]. When identification of a PCWDE was not clear, CAZymes Analysis Toolkit (CAT) was used [45].

\subsection{Identities Comparison of the Thecaphora frezii PCWDE's with their Orthologues from $U$. maydis, Thecaphora thlaspeos (T. thlaspeos), Anthracocystis flocculosa (A. flocculosa), Sporisorium reilianum (S. reilianum), Kalmanozyma brasiliensis (K. brasiliensis), Ustilago hordei (U. hordei) and Moesziomyces antarcticus (M. antarcticus)}

PCWDEs identities were compared and analyzed by multiple proteins sequence and pairwise alignments, omitting the SP (signal peptide) if it is present [46]. Proteins were considered to be homologues if they shared $25 \%$ or more identity with an alignment length greater $>80$ amino acids [47].

\section{7. qPCR Analysis of Selected Genes}

The transcripts of genes presents in the PCWDE families were quantified by 
real-time PCR. The oligonucleotides were designed using the program Primer-Blast (NCBI, NIH) (Table 1 shows the sequences of the primers of the ten genes with the highest FC, the rest, 30 genes, were in Table S1). Quantification of gene expression was performed using the StepOne Plus Real-Time PCR Detection System ${ }^{\circledR}$ (Thermo Fisher Scientific ${ }^{\mathrm{TM}}$, Massachusetts).

The cDNA was prepared from the same RNA samples used for RNA-Seq analysis using the enzyme SuperScript ${ }^{\circledR}$ III Reverse Transcriptase (Invitrogen; California) according to the manufacturer's recommendations. qPCR was performed with three technical replicates using the Sybr ${ }^{\circledR}$ Green Master Mix Kit (Applied Biosystems; Thermo Fisher Scientific ${ }^{\mathrm{TM}}$, California) according to the manufacturer's recommendations.

Relative gene expression was performed using the actin transcript as the reference gene for expression normalization (this gene is commonly used for normalization of fungal gene expression [48] [49] [50] [51] [52]). The program used for all targets was: $95 \mathrm{C}$ for 3 minutes, 40 cycles of $95 \mathrm{C}$ for 10 seconds and $60 \mathrm{C}$ for 30 seconds. After this step, the fluorescence was read. At the end of the program, the temperature was reduced from $95 \mathrm{C}$ to $65 \mathrm{C}$ with a rate ramp of 0.1 $\mathrm{C} / \mathrm{s}$, which allowed the evaluation of the melting curves for each reaction. The specificity of the amplicon was verified by analysis of the melting curves and by sequencing of the fragments obtained. The change in expression of the target gene relative to actin expression was calculated using the $2^{-\Delta \Delta \mathrm{CT}}$ method [53]. The mean and SE $( \pm)$ were, then, determined for each of the different samples.

\subsection{Statistical Analysis}

Statistical analysis was performed using InfoStat software [54]. All data were calculated as mean \pm standard deviation. Data were analyzed for statistical significance using the $t$-test.

Table 1. Real time PCR oligonucleotides.

\begin{tabular}{|c|c|c|c|c|}
\hline $\begin{array}{c}\text { GenBank } \\
\text { Accession } \\
\text { Numbers }\end{array}$ & Potential Protein Name & Primer Forward $\left(5^{\prime} \rightarrow 3^{\prime}\right)$ & Primer Reverse $\left(5^{\prime} \rightarrow 3^{\prime}\right)$ & $\begin{array}{c}\text { Amplification } \\
\text { Size (bp) }\end{array}$ \\
\hline MW602834 & putative GMC oxidoreductase & CTCAAGAAGACGCTCAAGGC & GATGATGCTCTCAGGGTGGT & 183 \\
\hline MW602838 & putative GMC oxidoreductase & CAGGGCTACAACCTCACGTA & GCAGACCTCCAAAGCTGATG & 100 \\
\hline MW602839 & putative GMC oxidoreductase & ACCCGAGAACAAGCCCATAA & GGAACCATGGAAAGGATGCC & 135 \\
\hline MW602840 & putative GMC oxidoreductase & GCAACCCTTACCTGCTGAAG & GATGGACGAGTCGACAAACG & 182 \\
\hline MW602841 & putative GMC oxidoreductase & ACCGACGTTGGCAAATATGG & GATGAGGGTGGCGAGGTTAT & 192 \\
\hline MW602847 & putative exo-beta-glucanase & CACCACAATCCAGGACCTCT & GAGTGAGGGATTCTGCCAGT & 121 \\
\hline MW602848 & putative glucan-beta-glucosidase & CGTGGAGCGACTTTGTCATT & AACCACTGAGTACTCGCCAA & 182 \\
\hline MW602849 & putative exo-beta-glucanase & CAGCACCTCAACACGTTCAT & TTCAGCAGGTCGTACTGGTT & 149 \\
\hline MW602850 & putative exo-1,3-beta-glucanase & AACTGGCTGCTGTTTGAAGG & ACTCGTCAAAGTGCTTCTGC & 166 \\
\hline MW602851 & putative glycoside hydrolase family & TCAACGAGCCCAACAACATC & GGTAGAGGCGGTAGACCTTG & 147 \\
\hline MW602863 & Actin & CTACGTTGCCCTCGACTTTG & CGTTTCCGACAGTGATGACC & 107 \\
\hline
\end{tabular}




\section{Results}

\subsection{Identification of $T$. frezii PCWDEs}

The analysis of the transcriptomes of the three ontogenetic stages of $T$. frezii (teliospores, basidiospores and hyphae), allowed us to search for enzymes that can degrade the plant cell wall (PCWDEs). Teliospores of $T$. frezii fungus was isolated and cultured in vitro to obtain its others ontogenetic stages (basidiospores and hyphae, Figure 1). The total RNA of the three stages was extracted and from there, the data generated by RNA-Seq was performed and analyzed. Based on these results, the respective protein sequences were deduced and transcripts were quantified (it must be taken into account that the quantifications carried out are made from the samples obtained according to the experimental conditions used, that is, culture for basidiospores and hyphae; and for teliospores, from peanut pods showing symptoms of disease).

Using the dbCAN2 metaserver (a web server), the presence of carbohydrate-active enzyme ANnotation modules were identified and these were analyzed complementarily with the MyHits, Prosite and BLASTp sites. From there, we focused on identifying the various enzymes that comprised the GH, PL, CE, $\mathrm{CBM}$ and AA modules. More than 135 translated mRNA were identified that had these features, but only 40 of them were compatible with the functions of the PCWDEs. 27 GH, 2 PL, 3 CE and 8 AA were detected (all sequences data were deposited into GenBank at https://www.ncbi.nlm.nih.gov/genbank/ site). Among them, 18 enzymes would degrade cellulose; 1 cutin; 1 galactomannan; 9 pectins; 7 xylans and 4 xyloglucans (Table 2 and Figure 2). In addition, this table compares the expressions of the different transcripts using the FC between basidiospore versus teliospore, and hyphae versus teliospore stages and shows the presumed EC number of enzymes and the CAZyme family to which they belong.

Cellulose: $T$. frezii expressed genes whose encoded proteins would potentially act on cellulose, eight were from AA and ten were from GH (Table 2 and Figure 2).

CAZy auxiliary activity family 3 (AA3) includes enzymes from the glucose-methanol-choline (GMC) family of oxidoreductases that support the activity of other AA family enzymes via their reaction products or support the action of glycoside hydrolases in lignocellulose degradation [55].

The transcript levels for five expressed AA3 genes were highest in the basidiospores and hyphae stages compared to teliospores, and only three are decreased in both stages. Under our conditions, a T. frezii AA3 enzyme (putative GMC oxidoreductase, MW602841) was the most highly expressed PCWDE gene.

The GH5 family has a range of activities and target substrates and has recently been classified into 51 subfamilies [56].

The $\beta$-glucosidases are predominantly found in the GH1 and GH3 families. However, these families also contain other glycosidases. A feature typical of most, but not all, cellulases, and also found in some other PCWDEs, is the presence of 
N. W. Soria et al.

Table 2. T. frezii PCWDE genes expressed at teliospores, basidiospore or hyphal stages.

\begin{tabular}{|c|c|c|c|c|c|c|c|c|}
\hline $\begin{array}{l}\text { GenBank } \\
\text { Accession } \\
\text { Numbers }\end{array}$ & $\begin{array}{c}\text { Overexpression } \\
\left(\mathrm{FC}^{\mathrm{a}} \mathrm{B} \text { vs. T) }\right.\end{array}$ & $\begin{array}{l}\text { Overexpression } \\
\left(\mathrm{FC}^{\mathrm{a}} \mathrm{H} \text { vs. } \mathrm{T}\right)\end{array}$ & Substrate & $\begin{array}{c}\text { EC } \\
\text { Number }\end{array}$ & $\begin{array}{c}\text { CAZyme } \\
\text { family }^{\mathrm{b}}\end{array}$ & $\begin{array}{c}\text { mRNA } \\
\text { expression } \\
\text { (Basidiospore) }\end{array}$ & $\begin{array}{c}\text { mRNA } \\
\text { expression } \\
{ }^{c}(\text { Hyphae })^{c}\end{array}$ & $\begin{array}{c}\text { mRNA } \\
\text { expression } \\
\text { (Teliospore) }^{c}\end{array}$ \\
\hline MW602835 & 0.91 & 0.17 & Cellulose & 1.1 .99 .18 & AA3 & 0.0703 & 0.0135 & 0.0773 \\
\hline MW602836 & 0.47 & 0.32 & Cellulose & 1.1 .99 .18 & AA3 & 0.0042 & 0.0029 & 0.0091 \\
\hline MW602837 & 0.64 & 0.58 & Cellulose & 1.1 .99 .18 & AA3 & 0.0792 & 0.0712 & 0.1233 \\
\hline MW602842 & 0.30 & 0.25 & Cellulose & 3.2.1.- & GH5 & 0.0089 & 0.0075 & 0.0297 \\
\hline MW602843 & 1.07 & 0.62 & Cellulose & 3.2.1.- & GH5 & 0.1832 & 0.1052 & 0.1708 \\
\hline MW602844 & 1.01 & 0.46 & Cellulose & 3.2.1.- & GH5 & 0.0665 & 0.0302 & 0.0658 \\
\hline MW602845 & 0.25 & 0.18 & Cellulose & 3.2 .1 .78 & GH5 & 0.0164 & 0.0117 & 0.0646 \\
\hline MW602846 & 0.21 & 0.16 & Cellulose & 3.2.1.58 & GH5 & 0.0453 & 0.0343 & 0.2179 \\
\hline MW602852 & 0.34 & 0.39 & Cutin & 3.1 .1 .74 & CE5 & 0.0506 & 0.0592 & 0.1508 \\
\hline MW602853 & 1.50 & 1.15 & Galactomannan & 3.2 .1 .22 & GH27 & 0.0009 & 0.0007 & 0.0006 \\
\hline MW602854 & 0.33 & 0.37 & Pectin & 3.2 .1 .172 & GH105 & 0.0061 & 0.0069 & 0.0187 \\
\hline MW602855 & 0.59 & 0.60 & Pectin & 3.2.1.31 & $\mathrm{GH} 2$ & 0.1867 & 0.1894 & 0.3174 \\
\hline MW602856 & 0.09 & 0.18 & Pectin & 3.2.1.15 & $\mathrm{GH} 28$ & 0.0016 & 0.0030 & 0.0173 \\
\hline MW602857 & 3.26 & 0.30 & Pectin & 3.2 .1 .15 & GH28 & 0.2733 & 0.0250 & 0.0839 \\
\hline MW602858 & 0.94 & 0.90 & Pectin & 3.2 .1 .15 & GH28 & 0.0350 & 0.0336 & 0.0374 \\
\hline MW602859 & 0.36 & 0.75 & Pectin & 3.2 .1 .99 & GH43 & 0.0584 & 0.1232 & 0.1640 \\
\hline MW602860 & 0.11 & 0.14 & Pectin & 3.2 .1 .89 & GH53 & 0.0418 & 0.0547 & 0.3930 \\
\hline MW602861 & 0.38 & 0.05 & Pectin & 4.2 .2 .2 & PL1 & 0.0076 & 0.0010 & 0.0200 \\
\hline MW602862 & 0.52 & 0.26 & Pectin & 4.2.2.23 & PL4 & 0.0277 & 0.0140 & 0.0537 \\
\hline MW602864 & 6.58 & 2.08 & Xylan & 3.2.1.8 & GH10 & 0.0276 & 0.0087 & 0.0042 \\
\hline MW602865 & 7.30 & 0.58 & Xylan & 3.2.1.99 & GH43 & 0.0382 & 0.0031 & 0.0052 \\
\hline MW602866 & 2.23 & 1.02 & Xylan & 3.2 .1 .55 & GH43 & 0.1381 & 0.0628 & 0.0618 \\
\hline MW602867 & 0.68 & 0.60 & Xylan & 3.2 .1 .8 & GH43 & 0.1000 & 0.0876 & 0.1461 \\
\hline MW602868 & 0.08 & 0.07 & Xylan & 3.2 .1 .55 & GH51 & 0.0106 & 0.0095 & 0.1315 \\
\hline MW602869 & 0.74 & 0.52 & Xylan & 3.1 .1 .72 & CE1 & 0.0313 & 0.0218 & 0.0423 \\
\hline MW602870 & 2.45 & 0.93 & Xylan & 3.1 .1 .73 & CE7 & 0.0292 & 0.0111 & 0.0119 \\
\hline MW602871 & 1.92 & 2.29 & Xyloglucan & 3.2.1.177 & GH31 & 0.0409 & 0.0487 & 0.0213 \\
\hline MW602872 & 0.42 & 0.17 & Xyloglucan & 3.2.1.177 & GH31 & 0.0358 & 0.0147 & 0.0853 \\
\hline MW602873 & 0.07 & 0.45 & Xyloglucan & 3.2 .1 .23 & GH42 & 0.0003 & 0.0018 & 0.0040 \\
\hline MW602874 & 0.26 & 0.37 & Xyloglutan & 3.2 .1 .23 & GH35 & 0.0338 & 0.0473 & 0.1283 \\
\hline
\end{tabular}

${ }^{a} \mathrm{FC}$, fold change difference between basidiospore (B) or hyphae (H) compared to teliospore (T) stage. ${ }^{\mathrm{b}} \mathrm{GH}$, glycoside hydrolases; AA, Auxiliary Activities; CE, Carbohydrate Esterases; PL, Polyssacharides Lyases. Numbers associated with CAZy types refer to the family number. ${ }^{\mathrm{C}} \mathrm{Mean}$ of three technical replicates normalized by actin expression. 


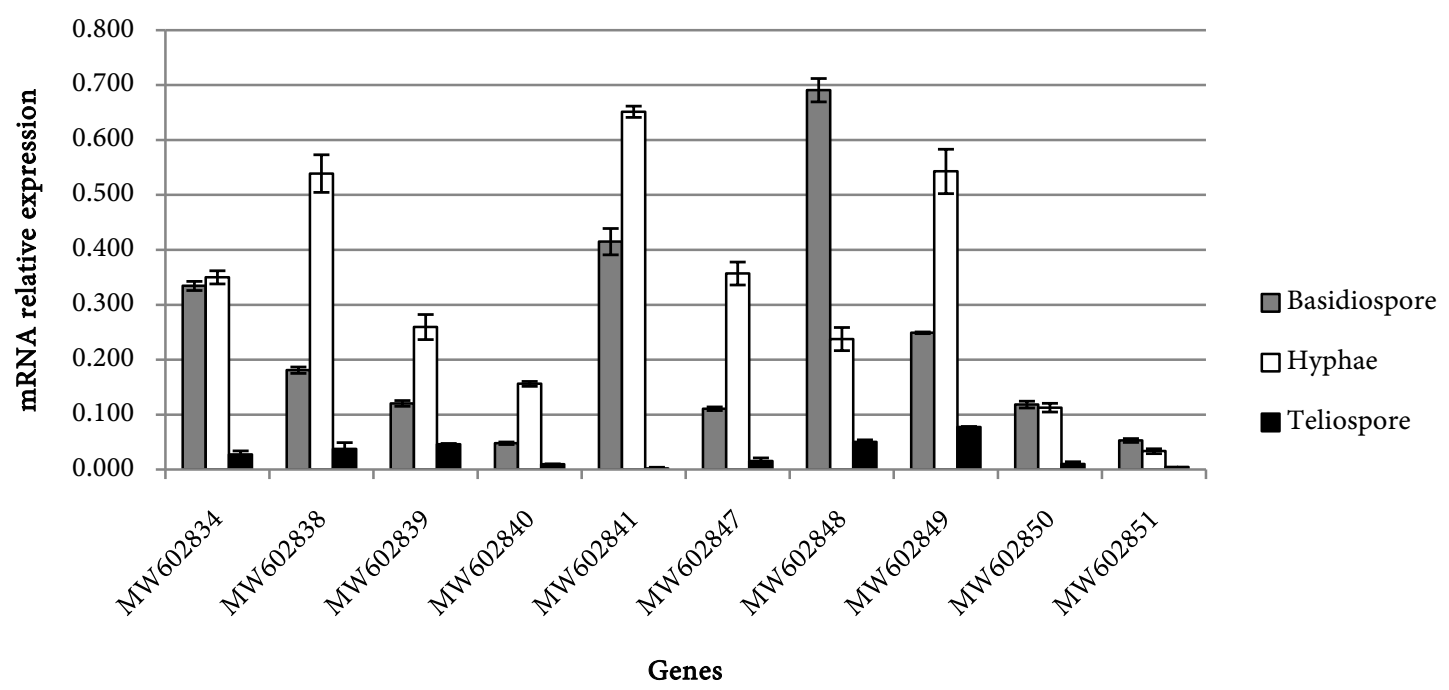

Figure 2. PCWDE mRNA expression levels from T. frezii according to their ontogenetic stages. The mean and SE $( \pm)$ were determined for each of the different samples (technical triplicates normalized with actin transcript). List of genes from which the corresponding proteins are deduced, all having cellulose as a substrate: 1 ) Putative GMC oxidoreductase (MW602834); 2) Putative GMC oxidoreductase (MW602838); 3) Putative GMC oxidoreductase (MW602839); 4) Putative GMC oxidoreductase (MW602840); 5) Putative GMC oxidoreductase (MW602841); 6) Putative exo-beta-glucanase (MW602847); 7) Putative glucan-beta-glucosidase (MW602848); 8) Putative exo-beta-glucanase (MW602849); 9) Putative exo-1,3-beta-glucanase (MW602850); and 10) Putative glycoside hydrolase family (MW602851). The first 5 genes belong to the AA3 family, from genes 6 to 9 to the GH5 family and the gene 10 to the GH1 family.

a polysaccharide that binds to a domain linked by a hinge region that aids in the binding of cellulases to their insoluble substrates [8]. We found high expression of a GH1 (putative glycoside hydrolase family 1, MW602851) in both basidiospores and hyphae stages (Table 2 and Figure 2).

Galactomannan: Alpha-galactosidases catalyze the hydrolysis of terminal alpha-1,6-galactosyl units from galacto-oligosaccharides and polymeric galactomannans and are assigned to glycosyl hydrolase family 27 (GH27), for which several members are structurally known (CAZy) [57]. We found only one transcript (putative alpha-galactosidase, MW602853) with these properties and its expression was 1.15- and 1.50-fold higher in hyphae and basidiospores, respectively, than in teliospores (Table 2).

Xylan: Many proteins encoded by genes of the GH and CE families act on hemicellulose as well as a number of other polysaccharides. Although some genes targeting hemicellulose were expressed during all ontogenetic stages, the highest transcript levels were observed mainly during the basidiospores stage (Table 2 and Figure 2).

GH10 proteins are endo- $\beta$-1,4-xylanases that act on xylans, glucuronoxylans and glucuronoarabinoxylans [3], and we found one whose gene expression peaked during the basidiospore stage (Table 2 and Figure 2).

Three different GH43s were found, arabinase; alpha-l-arabinofuranosidase and endo-beta-1,4-xylanase (MW602865; MW602866 and MW602867, respectively). The MW602865 transcript was found to be seven FC more expressed in 
basidiospores compared to teliospores (Table 2 and Figure 2).

Another enzyme of the glycoside hydrolase family expressed in different stages of T. frezii was alpha-L-arabinofuranosidase (GH51) (MW602868), whose level was 13- to 12 -fold higher in teliospores compared with hyphae and basidiospores, respectively (Table 2 and Figure 2). Other gene family whose expression was slowly increased in basidiospores and is thought to encode hemicellulose-directed enzymes was CE7 esterase, which remove the acetyl moiety of xylans (Table 2 and Figure 2).

Xyloglucan: As shown in Table 2 and Figure 2, two alpha-xylosidases releasing alpha-xylose from xyloglucan oligosaccharides belonging to the GH31 family were identified.

Two beta-galactosidases were found (MW602873 and MW602874), belonging to the GH42 and GH35 families, respectively. Their expressions are decreasing from teliospores, passing through hyphae and their lowest expression was found in basidiospores (Table 2 and Figure 2).

Pectin: The transcriptome of $T$. frezii contains nearly nine PCWDEs that are likely to act specifically on pectins. These nine PCWDEs are derived from seven CAZyme families. Only one transcript is overexpressed in the basidiospore stage compared to what is expressed in teliospores (MW602857) and all transcript were down-regulated in the hyphae stage, also compared to the expression that occurs in teliospores (MW602854, MW602855, MW602856, MW602857, MW602858, MW602859, MW602860, MW602861, MW602862).

Within the families of glycoside hydrolases, we found one GH105 with unsaturated rhamnogalacturonyl hydrolase (MW602854); one GH2 with beta-glucuronidase (MW602855); three GH28s with endo-polygalacturonase (MW602856, MW602857, and MW602858); one GH43 with arabinan endo-1,5-alpha-L-arabinanase (MW602866); and one GH53 with arabinogalactan endo-beta-1,4-galactanase (MW602860) activities. We also found two pectin lyases, PL1 and PL4, with pectate lyase (MW602861) and rhamnogalacturonan endolyase (MW602862) similarities, respectively; both express mainly in teliospores (Table 2 and Figure 2).

Cutin: Cutin is composed of hydroxy and hydroxyepoxy fatty acids. Cutinases (family CE5) catalyze the cleavage of the ester bonds of cutin to release cutin monomers. There are several fungi that express these enzymes [11]. In our samples, we found similar levels of expression in basidiospores and hyphae and approximately 3 fold higher in teliospores (Table 2 ).

Although in the $T$. frezii transcriptome the number of genes with CAZy domains was higher than those we showed (more than 135), we only list transcripts that we could detect possible PCWDE activity using websites tools. An additional complication we encountered was that the genome of $T$. frezii is unknown. If it were available, it would allow us to make more and better comparisons, particularly with similar species.

In addition, we compared the identity of each of the derived enzymes of $T$. 
frezii with their orthologues from U. maydis, T. thlaspeos, A. flocculosa, S. reilianum, $K$. brasiliensis, $U$. hordei and $M$. antarcticus (because they belong to the same taxonomic class (Ustilaginomycetes), and some of them are phytopathogenics, generating smut diseases (Table 3 and Table S2).

Table 3. Analysis of T. frezii PCWDE (length and identities comparison with U. maydis, T. thlaspeos, A. flocculosa and U. hordei).

\begin{tabular}{|c|c|c|c|c|c|}
\hline $\begin{array}{c}\text { PCWDE GenBa } \\
\text { Accession } \\
\text { Numbers }\end{array}$ & $\begin{array}{l}\text { Deduced Protein } \\
\text { Length (number } \\
\text { of amino acids) }\end{array}$ & Percentage (\%) & of Protein Identity/Acce & ssion Number of Ref & rence Sequence \\
\hline \multicolumn{2}{|c|}{ Thecaphora frezii } & Ustilago maydis & Thecaphora thlaspeos & $\begin{array}{c}\text { Anthracocystis } \\
\text { flocculosa }\end{array}$ & Ustilago hordei \\
\hline MW602834 & 600 & 83/XP_011386298.1 & 80/UWYS01000020.1 & 87/XP_007882019.1 & 83/XP_041409722.1 \\
\hline MW602835 & 710 & 75/XP_011387932.1 & 82/UWYS01000014.1 & 84/XP_007879028.1 & 74/XP_041411102.1 \\
\hline MW602836 & 564 & 55/XP_011389669.1 & 76/UWYS01000011.1 & 75/XP_007881316.1 & 54/XP_041415878.1 \\
\hline MW602837 & 610 & 75/XP_011387685.1 & 82/UWYS01000003.1 & 86/XP_007879328.1 & 76/XP_041411430.1 \\
\hline MW602838 & 692 & 57/XP_011391368.1 & 62/UWYS01000029.1 & 68/XP_007878618.1 & 54/XP_041413656.1 \\
\hline MW602839 & 628 & 60/XP_011387810.1 & 72/UWYS01000022.1 & 78/XP_007882371.1 & 29/XP_041415878.1 \\
\hline MW602840 & 697 & 68/XP_011390038.1 & 76/UWYS01000009.1 & 79/XP_007878320.1 & 43/GAC71446.1 \\
\hline MW602841 & 623 & 55/XP_011389987.1 & 70/UWYS01000009.1 & 73/XP_007878214.1 & 54/XP_041411913.1 \\
\hline MW602842 & 818 & 63/XP_011386174.1 & 69/UWYS01000001.1 & 69/XP_007876186.1 & 62/XP_041409506.1 \\
\hline MW602843 & 882 & 57/XP_011390266.1 & 68/UWYS01000006.1 & 77/XP_007879865.1 & 59/XP_041413492.1 \\
\hline MW602844 & 476 & 55/XP_011391775.1 & 67/UWYS01000014.1 & 74/XP_007880014.1 & 54/XP_041412014.1 \\
\hline MW602845 & 511 & 67/XP_011387602.1 & 57/UWYS01000003.1 & 69/XP_007879449.1 & $\mathrm{ND} / \mathrm{ND}$ \\
\hline MW602846 & 463 & 64/XP_011386164.1 & 59/UWYS01000001.1 & 73/XP_007876246.1 & 62/XP_041409492.1 \\
\hline MW602847 & 535 & 31/XP_011386896.1 & 73/UWYS01000015.1 & 75/XP_007881477.1 & 35/XP_041409492.1 \\
\hline MW602848 & 632 & 52/XP_011392454.1 & 64/UWYS01000007.1 & 65/XP_007877815.1 & 52/XP_041412344.1 \\
\hline MW602849 & 517 & 59/XP_011391862.1 & 72/UWYS01000023.1 & 73/XP_007881381.1 & 57/XP_041414386.1 \\
\hline MW602850 & 628 & 65/XP_011386896.1 & 73/UWYS01000029.1 & 76/XP_007878549.1 & 66/XP_041415648.1 \\
\hline MW602851 & 409 & $\mathrm{ND} / \mathrm{ND}$ & 72/UWYS01000006.1 & 76/XP_007881827.1 & $\mathrm{ND} / \mathrm{ND}$ \\
\hline MW602852 & 259 & 61/XP_011386312.1 & 65/UWYS01000015.1 & 59/XP_007880759.1 & 62/CCF54195.1 \\
\hline MW602853 & 365 & 57/XP_011390836.1 & $\mathrm{ND} / \mathrm{ND}$ & 60/XP_007878151.1 & 39/CCF50716.1 \\
\hline MW602854 & 396 & 66/XP_011387870.1 & 697 UWYS01000003.1 & 75/XP_007882544.1 & 67/XP_041411152.1 \\
\hline MW602855 & 664 & $\mathrm{ND} / \mathrm{ND}$ & $\mathrm{ND} / \mathrm{ND}$ & 60/XP_007878519.1 & 53/XP_041415678.1 \\
\hline MW602856 & 376 & 55/XP_011388929.1 & 43/UWYS01000002.1 & 56/XP_007879026.1 & 57/XP_041414954.1 \\
\hline MW602857 & 462 & 26/XP_011388929.1 & 57/UWYS01000017.1 & 60/XP_007880267.1 & ND/ND \\
\hline MW602858 & 358 & 64/XP_011388929.1 & 65/UWYS01000014.1 & 65/XP_007879026.1 & 64/XP_041414954.1 \\
\hline MW602859 & 315 & $\mathrm{ND} / \mathrm{ND}$ & 59/UWYS01000014.1 & 67/XP_007880158.1 & $\mathrm{ND} / \mathrm{ND}$ \\
\hline MW602861 & 388 & 47/XP_011391598.1 & 66/UWYS01000006.1 & 66/XP_007876158.1 & ND/ND \\
\hline MW602862 & 685 & $\mathrm{ND} / \mathrm{ND}$ & 58/UWYS01000001.1 & 61/XP_007879517.1 & 45/XP_041412196.1 \\
\hline
\end{tabular}




\begin{tabular}{|c|c|c|c|c|c|}
\hline MW602860 & 355 & ND/ND & 53/UWYS01000016.1 & 68/XP_007879956.1 & ND/ND \\
\hline MW602864 & 340 & 50/XP_011389883.1 & 53/UWYS01000019.1 & 51/XP_007880950.1 & 47/XP_041411767.1 \\
\hline MW602865 & 300 & 50/XP_011389888.1 & 81/UWYS01000010.1 & 79/XP_007878036.1 & 30/XP_041414991.1 \\
\hline MW602866 & 406 & 62/XP_011387715.1 & 69/UWYS01000010.1 & 81/XP_007878081.1 & $\mathrm{ND} / \mathrm{ND}$ \\
\hline MW602867 & 388 & 69/XP_011391222.1 & 65/UWYS01000001.1 & 76/XP_007876316.1 & 65/XP_041413719.1 \\
\hline MW602868 & 317 & 48/XP_011386874.1 & 64/UWYS01000013.1 & 66/XP_007878998.1 & 50/XP_041415698.1 \\
\hline MW602869 & 311 & 64/XP_011391122.1 & 56/UWYS01000015.1 & 71/XP_007881474.1 & 63/XP_041414473.1 \\
\hline MW602870 & 594 & $\mathrm{ND} / \mathrm{ND}$ & 53/UWYS01000019.1 & 53/XP_007881882.1 & 27/XP_041412944.1 \\
\hline MW602871 & 1069 & 73/XP_011391102.1 & 81/UWYS01000023.1 & 80/SPO40945.1 & 72/XP_041414441.1 \\
\hline MW602872 & 880 & 61/XP_011387863.1 & 91/UWYS01000003.1 & 74/XP_007882546.1 & 61/XP_041411161.1 \\
\hline MW602873 & 787 & 60/XP_011388548.1 & 77/UWYS01000001.1 & 79/XP_007875969.1 & 62/XP_041413828.1 \\
\hline MW602874 & 547 & 65/XP_011388663.1 & 73/UWYS01000008.1 & 71/XP_007877405.1 & 60/XP_041412864.1 \\
\hline
\end{tabular}

ND: no data.

\subsection{Snf1 Expression}

In T. frezii transcriptome, we found a transcript that, when translated into a protein, has a sequence compatible with the Snf1 protein (MW691285) because it has 763 amino acids in length, the conserved threonine at position 202 (which is critical for activation by upstream kinases), and has $68 \%$ identity to the $U$. maydis orthologue (Figure S1). Furthermore, the identity at the protein level found with other Ustilaginomycetes was: T. thlaspeos (71\%), A. flocculosa (76\%), S. reilianum (69\%), $K$. brasiliensis (71\%), U. hordei (69\%) and M. antarcticus (69\%). It is also interesting to note that the relative expression levels in basidiospores (0.016) and hyphae (0.022) were significantly lower compared to teliospores (0.325).

\section{Discussion}

The plant surface is the first line of defense to prevent pathogens from penetrating and causing infection. The composition and structure of cell walls make it difficult for the pathogen to advance. Cell walls are made up of celluloses, hemicelluloses, pectins, structural proteins, and middle lamellae, which consist mainly of pectins. To overcome this line of defense, fungi generally secrete a mixture of hydrolytic enzymes including cutinases, cellulases, pectinases, and proteases.

Some of the fungi responsible for diseases in peanuts include the genera $A s$ pergillus, Penicillium, Sclerotinia, Fusarium, Rhizopus and Thecaphora [17] [18] [19] [58]. For example, Fusarium oxysporum produces several enzymes that act upon the pectic and cellulose components of cell walls of host plant [59].

The phytopathogenicity of some fungi is related to the expression of certain enzymes, which are classified as Plant Cell Wall-Degrading Enzymes. Many fungi expressing these enzymes have different diets; they can be saprophytic, hemibiotrophic and necrotrophic [3]. 
Through bioinformatics analysis, we identified transcripts in $T$. frezii that have the potential to translate and produce enzymes that form the PCWDE group. In parallel, our comparisons were mainly made with the enzymes expressed by the fungus $U$. maydis, T. thlaspeos, A. flocculosa, S. reilianum, $K$. brasiliensis, $U$. hordei and $M$. antarcticus (fungi of the same class). The highest identities of the deduced PCWDEs were found with their orthologues of $A$. flocculosa, T. thlaspeos and U. maydis, respectively. This could mean a greater phylogenetic closeness between these fungi. At the time of our analysis and based on the data deposited in the NCBI NIH database, there were only 4 proteins and 276 nucleotide sequences deposited for the taxonomy corresponding to Thecaphora. Therefore, we believe that the contribution of these sequences from the PCWDE of $T$. frezii may contribute to constructing some phylogenetic distances with fungi of the same class.

Forty candidate genes with PCWDE potential contributing to plant interaction and pathogenicity were expressed in $T$. frezii. They were classified into 27 glycoside hydrolases, two polysaccharide lyases, three carbohydrate esterases and eight enzymes with auxiliary activities.

For the degradation of cellulose, galactomannans, xylans, xyloglucans and pectin, fungi belonging to the phylum Basidiomycetes expressed the enzymes AA3, GH1 and GH5; GH27; GH10, GH43; GH31, GH35; GH105, GH2, GH28, GH43, GH53, PL1 and PL4, respectively, which is consistent with their occurrence in T. frezii [60].

On the other hand, it is well known that the Snf1 protein kinase is conserved in eukaryotic organisms. According to Ludin [61], in Saccharomyces cerevisiae, the SNF1 gene is essential for the transcription of genes repressed by glucose. The direct interaction between Snf1 and its activating subunit, Snf4, within the kinase complex is regulated by the glucose signal. In addition, they demonstrated that the catalytic domain of Snf1 presents a critical conserved amino acid threonine, at position 220. Our results in T. frezii show the presence of threonine at the critical site.

At the same time, according to the evidence by Ahuatzi [62], the Snf1 kinase is activated under low glucose conditions. Interestingly, in our work, we found very high levels of Snf1 in teliospores that, curiously, are not exposed to high levels of glucose, since they are found directly in the peanut pods. Meanwhile, low levels of expression of this gene are found in hyphae and basidiospores stages that are grown in medium with dextrose.

In this work, we sought to identify the presence of multiple PCWDEs (in the three ontogenetic stages of $T$. frezii) and we compare their identities with other fungi of the same class. The expression analyzed in this work is not necessarily the expression that occurs in the peanut plant, because the cultivation conditions of the three ontogenetic stages are not the same or similar to what happens in the plant, and this can also differentially regulate the expression of certain PCWDEs. Their expressions could be affected by transcriptional regulation dependent on genes such as SNF1 (whose expression varies depending on the car- 
bon source that the fungus uses). In our experimental conditions, basidiospores and hyphae are cultured with glucose, while teliospores are obtained directly from peanut fruit (teliospores cannot be cultured because they change their ontogenetic stage in the process). In this sense, it is logical to find a high level of Snf1 transcript in teliospores, compared to that of basidiospores and hyphae.

This is the first work that describes the expression of some enzymes with potential cell wall degradation activity in the peanut plant by the fungus $T$. frezii. These findings could contribute to understanding part of the mechanism by which $T$. frezii begins its infection process in peanut plants.

\section{Acknowledgements}

The present work was supported by grants from Universidad Católica de Córdoba, Fundación Maní Argentino and Centro de Excelencia en Productos y Procesos Córdoba (CEPROCOR).

\section{Conflicts of Interest}

The authors declare no conflicts of interest regarding the publication of this paper.

\section{References}

[1] Horbach, R., Navarro-Quesada, A.R., Knogge, W. and Deising, H.B. (2011) When and How to Kill a Plant Cell: Infection Strategies of Plant Pathogenic Fungi. Journal of Plant Physiology, 168, 51-62. https://doi.org/10.1016/j.jplph.2010.06.014

[2] Abdulkhair, W.M. and Alghuthaymi, M.A. (2016) Plant Pathogens. In: Rigobelo, E., Ed., Plant Growth, IntechOpen, London, 49-59. https://doi.org/10.5772/65325

[3] Kubicek, C.P., Starr, T.L. and Glass, N.L. (2014) Plant Cell Wall-Degrading Enzymes and Their Secretion in Plant-Pathogenic Fungi. Annual Review of Phytopathology, 52, 427-451. https://doi.org/10.1146/annurev-phyto-102313-045831

[4] Vorwerk, S., Somerville, S. and Somerville, C. (2004) The Role of Plant Cell Wall Polysaccharide Composition in Disease Resistance. Trends in Plant Science, 9, 203-209. https://doi.org/10.1016/j.tplants.2004.02.005

[5] Williamson, G., Kroon, P.A. and Faulds, C.B. (1998) Hairy Plant Polysaccharides: A Close Shave with Microbial Esterases. Microbiology, 144, 2011-2023. https://doi.org/10.1099/00221287-144-8-2011

[6] Hückelhoven, R. (2007) Cell Wall-Associated Mechanisms of Disease Resistance and Susceptibility. Annual Review of Phytopathology, 45, 101-127. https://doi.org/10.1146/annurev.phyto.45.062806.094325

[7] Henrissat, B., Coutinho, P.M. and Davies, G.J. (2001) A Census of Carbohydrate-Active Enzymes in the Genome of Arabidopsis Thaliana. Plant Molecular Biology, 47, 55-72. https://doi.org/10.1023/A:1010667012056

[8] Boraston, A.B., Bolam, D.N., Gilbert, H.J. and Davies, G.J. (2004) CarbohydrateBinding Modules: Fine-Tuning Polysaccharide Recognition. Biochemical Journal, 382, 769-781. https://doi.org/10.1042/BJ20040892

[9] Cantarel, B.L., Coutinho, P.M., Rancurel, C., Bernard, T., Lombard, V. and Henrissat, B. (2009) The Carbohydrate-Active EnZymes Database (CAZy): An Expert Resource for Glycogenomics. Nucleic Acids Research, 37, D233-D238. 
https://doi.org/10.1093/nar/gkn663

[10] Levasseur, A., Drula, E., Lombard, V., Coutinho, P.M. and Henrissat, B. (2013) Expansion of the Enzymatic Repertoire of the CAZy Database to Integrate Auxiliary Redox Enzymes. Biotechnology for Biofuels, 6, Article No. 41. https://doi.org/10.1186/1754-6834-6-41

[11] Zhao, Z., Liu, H., Wang, C. and Xu, J.-R. (2014) Comparative Analysis of Fungal Genomes Reveals Different Plant Cell Wall Degrading Capacity in Fungi. BMC Genomics, 15, Article No. 6. https://doi.org/10.1186/1471-2164-15-6

[12] Krapovickas, A. and Gregory, W.C. (2007) Taxonomía Del Género Arachis (Leguminosae). Bonplandia, 16, 1. https://doi.org/10.30972/bon.160158

[13] Córdoba Bolsa de Cereales (2015) Campaña 2014/2015. Producción Final de Maní, Córdoba, Argentina. Informe Especial No. 69.

[14] Pitt, J.I., Dyer, S.K. and McCammon, S. (1991) Systemic Invasion of Developing Peanut Plants by Aspergillus flavus. Letters in Applied Microbiology, 13, 16-20.

https://doi.org/10.1111/j.1472-765X.1991.tb00558.x

[15] Fernandez, E.M., Rosolem, C.A., Maringoni, A.C. and Oliveira, D.M.T. (1997) Fungus Incidence on Peanut Grains as Affected by Drying Method and Ca Nutrition. Field Crops Research, 52, 9-15. https://doi.org/10.1016/S0378-4290(96)03461-2

[16] Rossetto, C.A.V., Viegas, É. de C. and Lima, T. de M. (2003) Contaminação Fúngica Do Amendoim Em Função Das Doses de Calcário e Épocas de Amostragem. Bragantia, 62, 437-445. https://doi.org/10.1590/S0006-87052003000300010

[17] Backman, P.A., Bell, D.K., Ben-Yephet, Y., Beute, M.K., Black, M.C., Boswell, T.E., et al. (1997) Compendium of Peanut Diseases. 2nd Edition. American Phytopathological Society, Saint Paul.

[18] Cavallo, A., Novo, R. and Pérez, M. (2005) Eficiencia de Fungicidas En El Control de La Flora Fúngica Transportada Por Semillas de Maní (Arachis hypogaea L.) En La Argentina. Agriscientia, 22, 9-16.

http://www.revistas.unc.edu.ar/index.php/agris/article/view/2674

[19] Marinelli, A., March, G.J. and Oddino, C. (2008) Aspectos Biológicos y Epidemiológicos Del Carbón Del Maní (Arachis hypogaea L.) Causado Por Thecaphora Frezii Carranza \& Lindquist. AgriScientia, 25, 1-5.

[20] Carranza, J.M. and Lindquist, J.C. (1962) Thecaphora frezii n. Sp., Parásita de Arachis sp. Boletín de la Sociedad Argentina de Botánica, 10, 11-18.

[21] Marinelli, A., March, G. and Rago, A. (1995) El Carbón Del Maní Thecaphora Frezii Sobre Arachis hypogaea L. Resúmenes VII Congreso Argentino de Micología y XVII Jornadas Argentinas de Micología, Rosario, Argentina, 134.

[22] Cazzola, N., Gateau, M., March, G., Marinelli, A., García, J., Rago, A., et al. (2012) Intensidad y Pérdidas Ocasionadas Por Carbón Del Maní Según Regiones de Producción. $27^{\circ}$ Jornada Nacional de Maní, 34-35.

[23] Astiz Gassó, M. and Marinelli, A. (2003) Cultivo in Vitro de Thecaphora Frezii (Ustilaginales) Carbón Del Maní (Arachis hypogaea L). Boletín de La Sociedad Argentina de Botánica, 256.

[24] Cazón, L.I., Paredes, J.A. and Rago, A.M. (2018) The Biology of Thecaphora frezii Smut and Its Effects on Argentine Peanut Production. In: Kimatu, J.N., Eds., $A d$ vances in Plant Pathology, IntechOpen, London, 31-46.

https://doi.org/10.5772/intechopen.75837

[25] Soria, N.W., Díaz, M.S., Figueroa, A.C., Alasino, V.R., Yang, P. and Beltramo, D.M. 
(2021) Identification of Chitin Synthase and Chitinase Genes in Three Ontogenetic Stages from Thecaphora frezii, the Causal Agent of Peanut Smut Disease. Physiological and Molecular Plant Pathology, 116, Article ID: 101727. https://doi.org/10.1016/j.pmpp.2021.101727

[26] Ruiz-Herrera, J., Leon, C.G., Guevara-Olvera, L. and Carabez-Trejo, A. (1995) Yeast-Mycelial Dimorphism of Haploid and Diploid Strains of Ustilago maydis. Microbiology, 141, 695-703. https://doi.org/10.1099/13500872-141-3-695

[27] Adolfo, A., López, C., Aboites, R., Eréndira, H., Ambriz, G. and Herrera, R. (2010) Identification of Proteins Secreted by the Fungus Ustilago maydis (De Candole) Corda (Basidiomicete) Grown under in Vitro Conditions. Revista Electrónica Nova Scientia, 2, 104-130.

[28] Tudzynski, P. and Sharon, A. (2003) Fungal Pathogenicity Genes. Applied Mycology and Biotechnology, 3, 187-212. https://doi.org/10.1016/S1874-5334(03)80012-6

[29] Mathioni, S.M., Beló, A., Rizzo, C.J., Dean, R.A. and Donofrio, N.M. (2011) Transcriptome Profiling of the Rice Blast Fungus during Invasive Plant Infection and in Vitro Stresses. BMC Genomics, 12, Article No. 49. https://doi.org/10.1186/1471-2164-12-49

[30] Martínez-Soto, D., Robledo-Briones, A.M., Estrada-Luna, A.A. and Ruiz-Herrera, J. (2013) Transcriptomic Analysis of Ustilago maydis Infecting Arabidopsis Reveals Important Aspects of the Fungus Pathogenic Mechanisms. Plant Signaling \& Behavior, 8, Article ID: e25059. https://doi.org/10.4161/psb.25059

[31] Nadal, M., Garcia-Pedrajas, M.D. and Gold, S.E. (2010) The SNF11 Gene of Ustilago maydis Acts as a Dual Regulator of Cell Wall Degrading Enzymes. Phytopathology, 100, 1364-1372. https://doi.org/10.1094/MPMI-09-09-0217

[32] Tzima, A.K., Paplomatas, E.J., Rauyaree, P., Ospina-Giraldo, M.D. and Kang, S. (2011) VdSNF1, the Sucrose Nonfermenting Protein Kinase Gene of Verticillium dahliae, Is Required for Virulence and Expression of Genes Involved in Cell-Wall Degradation. Molecular Plant-Microbe Interactions, 24, 129-142. https://doi.org/10.1094/MPMI-09-09-0217

[33] Hedbacker, K. and Carlson, M. (2008) SNF1/AMPK Pathways in Yeast. Frontiers in Bioscience-Landmark, 13, 2408-2420. https://doi.org/10.2741/2854

[34] Robinson, M.D., McCarthy, D.J. and Smyth, G.K. (2010) EdgeR: A Bioconductor Package for Differential Expression Analysis of Digital Gene Expression Data. Bioinformatics, 26, 139-140. https://doi.org/10.1093/bioinformatics/btp616

[35] R Core Team (2018) R: A Language and Environment for Statistical Computing. R Foundation for Statistical Computing, Vienna. https://www.R-project.org/

[36] Yin, Y., Mao, X., Yang, J., Chen, X., Mao, F. and Xu, Y. (2012) DbCAN: A Web Resource for Automated Carbohydrate-Active Enzyme Annotation. Nucleic Acids Research, 40, W445-W451. https://doi.org/10.1093/nar/gks479

[37] Huang, L., Zhang, H., Wu, P., Entwistle, S., Li, X., Yohe, T., et al. (2018) DbCAN-Seq: A Database of Carbohydrate-Active Enzyme (CAZyme) Sequence and Annotation. Nucleic Acids Research, 46, D516-D521. https://doi.org/10.1093/nar/gkx894

[38] Blackman, L.M., Cullerne, D.P. and Hardham, A.R. (2014) Bioinformatic Characterisation of Genes Encoding Cell Wall Degrading Enzymes in the Phytophthora Parasitica Genome. BMC Genomics, 15, Article No. 785. https://doi.org/10.1186/1471-2164-15-785

[39] Pagni, M., Ioannidis, V., Cerutti, L., Zahn-Zabal, M., Jongeneel, C. V., Hau, J., et al. (2007) MyHits: Improvements to an Interactive Resource for Analyzing Protein Sequences. Nucleic Acids Research, 35, W433-W437. 
https://doi.org/10.1093/nar/gkm352

[40] Sigrist, C.J.A., de Castro, E., Cerutti, L., Cuche, B., Hulo, N., Bridge, A., et al. (2012) New and Continuing Developments at PROSITE. Nucleic Acids Research, 41, D344-D347.

[41] National Center for Biotechnology Information. http://www.ncbi.nlm.nih.gov

[42] El-Gebali, S., Mistry, J., Bateman, A., Eddy, S.R., Luciani, A., Potter, S.C., et al. (2019) The Pfam Protein Families Database in 2019. Nucleic Acids Research, 47, D427-D432. https://doi.org/10.1093/nar/gky995

[43] Altschul, S., Madden, T.L., Schäffer, A.A., Zhang, J., Zhang, Z., Miller, W., et al. (1997) Gapped BLAST and PSI-BLAST: A New Generation of Protein Database Search Programs. Nucleic Acids Research, 25, 3389-3402. https://doi.org/10.1093/nar/25.17.3389

[44] Lombard, V., Golaconda Ramulu, H., Drula, E., Coutinho, P.M. and Henrissat, B. (2014) The Carbohydrate-Active Enzymes Database (CAZy) in 2013. Nucleic acids research, 42, D490-D495. https://doi.org/10.1093/nar/gkt1178

[45] Park, B.H., Karpinets, T. V., Syed, M.H., Leuze, M.R. and Uberbacher, E.C. (2010) CAZymes Analysis Toolkit (CAT): Web Service for Searching and Analyzing Carbohydrate-Active Enzymes in a Newly Sequenced Organism Using CAZy Database. Glycobiology, 20, 1574-1584. https://doi.org/10.1093/glycob/cwq106

[46] Thompson, J.D., Higgins, D.G. and Gibson, T.J. (1994) CLUSTAL W: Improving the Sensitivity of Progressive Multiple Sequence Alignment through Sequence Weighting, Position-Specific Gap Penalties and Weight Matrix Choice. Nucleic Acids Research, 22, 4673-4680. https://doi.org/10.1093/nar/22.22.4673

[47] Sander, C. and Schneider, R. (1991) Database of Homology-Derived Protein Structures and the Structural Meaning of Sequence Alignment. Proteins: Structure, Function, and Genetics, 9, 56-68. https://doi.org/10.1002/prot.340090107

[48] Mosquera, G., Giraldo, M.C., Khang, C.H., Coughlan, S. and Valent, B. (2009) Interaction Transcriptome Analysis Identifies Magnaporthe oryzae BAS1-4 as Biotrophy-Associated Secreted Proteins in Rice Blast Disease. The Plant Cell, 21, 1273-1290. https://doi.org/10.1105/tpc.107.055228

[49] Song, Y.D., Hsu, C.C., Lew, S.Q. and Lin, C.H. (2020) Candida Tropicalis RON1 Is Required for Hyphal Formation, Biofilm Development, and Virulence but Is Dispensable for N-Acetylglucosamine Catabolism. Medical Mycology, 59, 379-391. https://doi.org/10.1093/mmy/myaa063

[50] Geiser, E., Reindl, M., Blank, L.M., Feldbrügge, M. and Wierckx, N. (2016) Activating Intrinsic Carbohydrate-Active Enzymes of the Smut Fungus Ustilago maydis for the Degradation of Plant Cell Wall Components. Applied and Environmental Microbiology, 82, 5174-5185. https://doi.org/10.1128/AEM.00713-16

[51] Soberanes-Gutiérrez, C. V., Pérez-Rueda, E., Ruíz-Herrera, J. and Galán-Vásquez, E. (2021) Identifying Genes Devoted to the Cell Death Process in the Gene Regulatory Network of Ustilago maydis. Frontiers in Microbiology, 12, Article ID: 680290. https://doi.org/10.3389/fmicb.2021.680290

[52] Darino, M., Chia, K., Marques, J., Aleksza, D., Soto-Jiménez, L.M., Saado, I., et al. (2021) Ustilago Maydis Effector Jsi1 Interacts with Topless Corepressor, Hijacking Plant Jasmonate/Ethylene Signaling. New Phytologist, 229, 3393-3407. https://doi.org/10.1111/nph.17116

[53] Livak, K.J. and Schmittgen, T.D. (2001) Analysis of Relative Gene Expression Data Using Real-Time Quantitative PCR and the $2^{-\Delta \Delta C T}$ Method. Methods, 25, 402-408. https://doi.org/10.1006/meth.2001.1262 
[54] Di Rienzo, J.A., Casanoves, F., Balzarini, M.G., Gonzalez, L., Tablada, M. and Robledo, C.W. (2016) InfoStat Versión 2016. Grupo Infostat, FCA, Universidad Nacional de Córdoba, Argentina. https://www.infostat.com.ar

[55] Sützl, L., Laurent, C.V.F.P., Abrera, A.T., Schütz, G., Ludwig, R. and Haltrich, D. (2018) Multiplicity of Enzymatic Functions in the CAZy AA3 Family. Applied Microbiology and Biotechnology, 102, 2477-2492. https://doi.org/10.1007/s00253-018-8784-0

[56] Aspeborg, H., Coutinho, P.M., Wang, Y., Brumer, H. and Henrissat, B. (2012) Evolution, Substrate Specificity and Subfamily Classification of Glycoside Hydrolase Family 5 (GH5). BMC Evolutionary Biology, 12, Article No. 186.

https://doi.org/10.1186/1471-2148-12-186

[57] Fernández-Leiro, R., Pereira-Rodríguez, Á., Cerdán, M.E., Becerra, M. and SanzAparicio, J. (2010) Structural Analysis of Saccharomyces Cerevisiae $\alpha$-Galactosidase and Its Complexes with Natural Substrates Reveals New Insights into Substrate Specificity of GH27 Glycosidases. Journal of Biological Chemistry, 285, 28020-28033. https://doi.org/10.1074/jbc.M110.144584

[58] Marinelli, A.D., March, G.J. and Oddino, C.M. (2017) Enfermedades Fúngicas Del Maní. In: Giayetto, E.M., Ed., El Cultivo Del Maní En Córdoba, 2nd Edition, Río Cuarto, Córdoba, 285-317.

[59] Rajeswari, P. (2015) In Vitro Inhibition of Cellulolytic Enzymes of Fusarium Oxysporum by Trichoderma Spp and Pseudomonas Fluorescens on Arachis hypogaea L. International Journal of Applied Sciences and Biotechnology, 3, 106-110. https://doi.org/10.3126/ijasbt.v3i1.12138

[60] Rytioja, J., Hildén, K., Yuzon, J., Hatakka, A., de Vries, R.P. and Mäkelä, M.R. (2014) Plant-Polysaccharide-Degrading Enzymes from Basidiomycetes. Microbiology and Molecular Biology Reviews, 78, 614-649. https://doi.org/10.1128/MMBR.00035-14

[61] Ludin, K., Jiang, R. and Carlson, M. (1998) Glucose-Regulated Interaction of a Regulatory Subunit of Protein Phosphatase 1 with the Snf1 Protein Kinase in Saccharomyces cerevisiae. Proceedings of the National Academy of Sciences of the United States of America, 95, 6245-6250. https://doi.org/10.1073/pnas.95.11.6245

[62] Ahuatzi, D., Riera, A., Peláez, R., Herrero, P. and Moreno, F. (2007) Hxk2 Regulates the Phosphorylation State of Mig1 and Therefore Its Nucleocytoplasmic Distribution. Journal of Biological Chemistry, 282, 4485-4493.

https://doi.org/10.1074/jbc.M606854200 


\section{Supplementary Material}

\author{
T.frezii \\ U.maydis 521 \\ T.frezii \\ U.maydis 521 \\ T.frezii \\ U.maydis 521 \\ T.frezii \\ U.maydis521 \\ T.frezii \\ U.maydis521 \\ T.frezii \\ U.maydis 521 \\ T.frezii \\ U.maydis 521 \\ T.frezii \\ U.maydis 521 \\ T.frezii \\ U.maydis521 \\ T.frezii \\ U.maydis521 \\ T.frezii \\ U.maydis 521 \\ T.frezii \\ U.maydis 521 \\ T.frezii \\ U.maydis 521 \\ T.frezii \\ U.maydis 521 \\ T.frezii \\ U.maydis521
}

----MSSSARS PGHAADANARA-SAKAASASTLGLGSGGKAAPKQPVRIGQYTLQQTLGT MSGRDASSRRQPSDHPDGAASSSRSSSRHPSRSGSVHRTKESTKQPVRIGQY ILQQTLGA

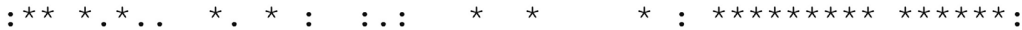
GSFGKVKLATHSLTGHRVAMKI INRRKISSLDMGGRVKREIQYLKLLRHPHI IKLYEVIT GSFGKVKLATHALTGHRVAMKI INRRKISSLDMGGRVKRE IQYLKLLRHPHI IKLYEVIT

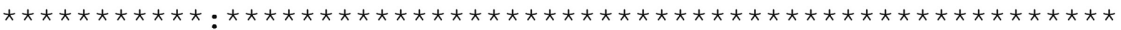
TPSDI IMVIEYAGGELFQYIVDRGRMSENEARRFFQQI ICAIEYCHRHKIVHRDLKPENL TPNDI IMVIEYAGGELFQYIVDRGRMPEHEARRFFQQVICAMEYCHRHKIVHRDLKPENL

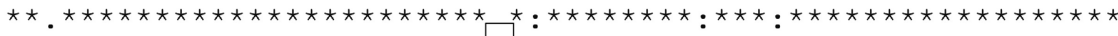
LLDEYLNVKIGDFGLSNIMTDGDFLKTSCGSPNYAAPEVISGRLYAGPEIDIWSCGVILY LLDEYLNVKIGDFGLSNIMTDGDFLKT:SCGSPNYAAPEVISGRLYAGPEIDIWSCGVILY

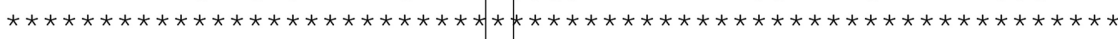
VMLCGRLPFDDEYIPTLFKKINGGIYTLPSFLSQEARHLLSQMLVVDPVKRITISEIRGH VMLCGRLPFDDEYIPTLFKKINNGIYTLPSYLSQEARHLLSQMLVVDPVKRITIQEIRQH

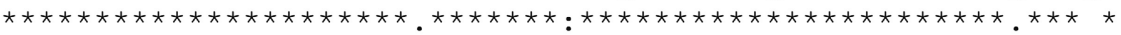
PWFNVDLPAYLRPLPPTPAVENAGFNFGISAMSECASAEDSSTSPS--------AAVAS PWFNVDLPAYLRPLPPTPATENHGFHFGMTAS PADTGSPADVTSPTNSSSAANSGASSQT

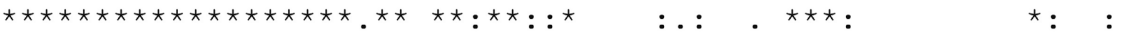
GSFSSRPGSQGQPTPDLGMIDPDIVDELVGKMVGFDREDVLHHLREKGDNQVKVAYQLVR SAPASRPGSQPIVTGDLGTIENDIVDELVGKMMGFNRDELMHHLTEKGDNQVKVAYQLVR

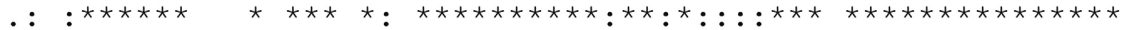
DHHRMLS IHHMEDQHGMENFLAQS P P PWNEGLDGVMARSTSLKRKPKLLERIATREGGNA DHRRMLQI HHMEDAHGMETFLAQS P PAWNEGLEGFMGRSTS IRRKNRDKEAAAVTSNKDQ

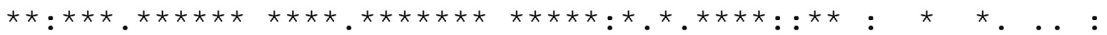
V----------------------AEEEAETS IMEPDAESDDGNETFASEDDDGL VPPLPTSAQAHVHAQAQAQAHAAVSGAGEDEGDSFTADVAEPEPSDDGNDTLASDDDDVL

$$
\text { * } \quad \text { * : : *: : ****:*:**:*** * }
$$
SDDDAHLIEEDDTEGARHTGIAVLETSLPGYLRAREAERLVTPSVERQPAWPKAGA---G TDDDGQLTDVEDGSAERIVRIAVLETSLPGFLRAREAERLATPSAEK-TSWPACTPIASA

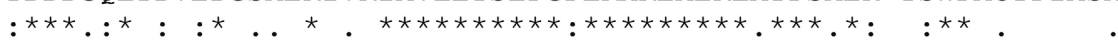
ITPVPLPPTTAQIHKKPRSRWHFGIRSRSPPME IMLELYRTLQVLGMEWRAKPSQAAAKA ATAALAQASTAQMHKKPRSRWHFGIRSRSPPMEIMLELYRTLQSLGMEWRAKPAAKQAKG

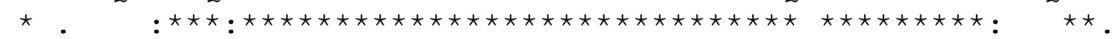
RDE----------DRKETHPEDASKGEELFFLETRWKVGDVLVRMDLQLYHVDSANFLV SGGDGAAGADDAKEKGKNASGSAVSKGEELFFLETRWKVGHVLVRMDLQLYHVDAANYLV

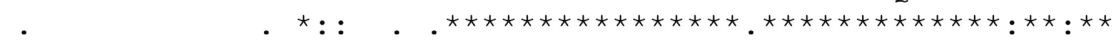
DFRNVGYTRLQRDASEA------------------DDAGSSPPPTVDANKLEAAFD DFRNVGYTTQETSFGSDDEHDGHDDQRDSAGNKSAAMEDGAGGAGGTAIMDVSKLEAAFD

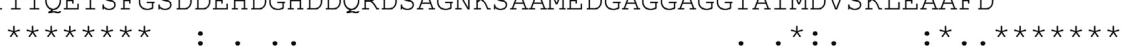
EVMTASQQALSDD-GLRKHRFDGSGRKPSLAPAVPAGRKEVNSPFLFLECATRLIVELAG KAMTEAQQAMQDGEHAGQHRFDGTRIKPSLAPAVPAGRKEVNSPFLFLECATRLIVELAG

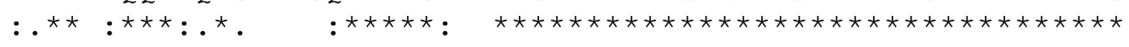
GS

GA *:

Figure S1. Sequence alignment of $T$. frezii and $U$. maydis Snf1 proteins. In the rectangle, the threonine conserved amino acid, at position 202. ${ }^{*}$ conserved amino acid, : strong amino acid conservation and, . weak amino acid conservation. 
N. W. Soria et al.

Table S1. Real Time PCR oligonucleotides.

\begin{tabular}{|c|c|c|c|}
\hline $\begin{array}{c}\text { GenBank } \\
\text { Accession } \\
\text { Numbers }\end{array}$ & Potential Gene Name & Primer Forward $\left(5^{\prime} \rightarrow 3^{\prime}\right)$ & $\begin{array}{c}\text { Amplification } \\
\text { Size (bp) }\end{array}$ \\
\hline MW602835 & putative GMC oxidoreductase & GCCGCCTTCATGACTAACTG GATCGAACCAGCCGAAACAA & 141 \\
\hline MW602836 & putative GMC oxidoreductase & GGCCCAACATCAAGGTCTTC GAGGCCCGACTTATCCTTGA & 110 \\
\hline MW602837 & putative GMC oxidoreductase & GAGGATCGAGGCATCATTGC GCTGCAGCTTGATACCTTCC & 160 \\
\hline MW602842 & putative Cellulase & GAGCTTCCGGCTAGGAGTAG GCTCCTTTGACAGCCAGATG & 128 \\
\hline MW602843 & putative Cellulase & TACGTCAAATCCTGGCCGAT TTTCATCCCACTCCCAGACC & 175 \\
\hline MW602844 & putative Cellulase & ATCCTGATGCACCTCGACAA GCGAGATGGTCTGGATGTTG & 169 \\
\hline MW602845 & putative Cellulase & CATTTCCTGGGCCAACAACA GTCGACGTAGTCGCTAAACG & 139 \\
\hline MW602846 & putative Cellulase & ATTGCGCAAGGTACCTCAAC AACATTTGGCGCAGGTAGTC & 151 \\
\hline MW602852 & putative Cutinase & CTTCATCCTGCAGGGCTACT GTTACCGATGAGCACGACAC & 109 \\
\hline MW602853 & putative Alpha 1,4 galactosidase & TGGAACACCTACACGGTCAA GAGAAGCGCGAGACAAAGTC & 104 \\
\hline MW602854 & putative Glycosyl hydrolase family 88 & GGTCGCATCATCGACACAAA CATGCGGTCTTCGAACCATT & 141 \\
\hline MW602855 & putative Glycosyl hydrolases family 2 & CTCGTCACCATCCACGACTA GGCGACAAAGATCGGATAGC & 108 \\
\hline MW602856 & Putative Glycosyl hydrolases family 28 & 3 AATGGGATCAGCCTCACCAA AATCCCTGCAACTTCCCTCA & 106 \\
\hline MW602857 & Putative Glycosyl hydrolases family 28 & AGCTGGTGATCTCCGACTTC AAGCGTGGTTGATGGTGATG & 177 \\
\hline MW602858 & Putative Glycosyl hydrolases family 28 & GCTTCGACTGTTGCTGTTCT TGGATGTTGCTCAGGGTGAT & 131 \\
\hline MW602859 & Putative Glycosyl hydrolases family 43 & 3 GTTTGGAACGGGCATCTACC CAGCACCTGTCAAACGAGAG & 171 \\
\hline MW602860 & Putative Glycosyl hydrolases family 53 & 3 ATCCAGGTGGTGGAAACCAA TGCTCTTCCAGAAGGGTTCC & 184 \\
\hline MW602861 & Putative Pectate lyase & TGTCACCGGCTATGACAACT TGTTGGCAAACGTGATCTGG & 146 \\
\hline MW602862 & Putative Polysaccharide lyase family 4 & CATCACGTCGGTCAACGAAA TGTAGTAGCGCGCAAAGTTC & 158 \\
\hline MW602864 & Putative Glycosyl hydrolase family 10 & CCAGGCTTGCAAGAGTATCG GCGGGCTTCTTGTTGTAGTT & 123 \\
\hline MW602865 & Putative Glycosyl hydrolase family 32 & CCATCTATCCCACCAGCGAT GTTCTCGTCCTTGGTGAAGC & 191 \\
\hline MW602866 & Putative Glycosyl hydrolase family 43 & AAATGGAAGCCAGCTGTACG TTAGCCTCGTTGCGGTAGAT & 102 \\
\hline MW602867 & Putative Glycosyl hydrolase family 43 & CGTACCTCACCTACCACCAG CGTGAAATGGCGAAGGATGT & 100 \\
\hline MW602868 & Putative Alpha-L-arabinofuranosidase & AGGTGATCAACACCAAGGCT ATACCCGTCAGCTGCCATAG & 106 \\
\hline MW602869 & Putative Acetylxylan esterase & TCGAGAAGCTCGAACAAGGT GATCCTCGGGCCTAAGTTGA & 96 \\
\hline MW602870 & Putative Feruloyl esterase & GGAAAGACATTCACGTGCGA AGGTTGGTGTCATAGCCGAA & 143 \\
\hline MW602871 & Putative Glycosyl hydrolases family 31 & I TACTACATCGGCGAGATCGG ATACGGCTTATCCTCGGCAA & 93 \\
\hline MW602872 & Putative Glycosyl hydrolases family 31 & I CAGAACCTACCCAGAAGCCA ATCGAGATCAAGGCGAGTGT & 108 \\
\hline MW602873 & Putative Beta-galactosidase & TCGGACATCGTCATCGAGTT TAGTGGTCGAAGTCGGTAGC & 110 \\
\hline MW602874 & Putative Glycosyl hydrolases family 35 & GTATCACGAAGCCACCAACC TGATTGGCO & 138 \\
\hline
\end{tabular}


Table S2. Analysis of T. frezii PCWDE (length and identities comparison with Sporisorium reilianum, Kalmanozyma brasiliensis and Moesziomyces antarcticus).

\begin{tabular}{|c|c|c|c|c|}
\hline \multirow{2}{*}{\multicolumn{2}{|c|}{$\begin{array}{c}\begin{array}{c}\text { PCWDE GenBank } \\
\text { Accession Numbers }\end{array} \\
\begin{array}{c}\text { Deduced Protein } \\
\text { amino acids) } \\
\text { amumber of }\end{array} \\
\text { Thecaphora frezii }\end{array}$}} & \multicolumn{3}{|c|}{ Percentage (\%) of Protein Identity/Accession Number of Reference Sequence } \\
\hline & & \multirow{2}{*}{$\begin{array}{c}\text { Sporisorium reilianum } \\
83 / \text { SJX60469.1 }\end{array}$} & \multirow{2}{*}{$\begin{array}{c}\text { Kalmanozyma brasiliensis } \\
\text { 83/XP_016295029.1 }\end{array}$} & \multirow{2}{*}{$\begin{array}{c}\text { Moesziomyces antarcticus } \\
\text { 83/XP_014659543.1 }\end{array}$} \\
\hline MW602834 & 600 & & & \\
\hline MW602835 & 710 & 75/SJX62136.1 & 74/XP_016292951.1 & 75/XP_014658543.1 \\
\hline MW602836 & 564 & 55/CBQ73647.1 & 28/XP_016292807.1 & 55/XP_014657062.1 \\
\hline MW602837 & 610 & 76/SJX61802.1 & 75/XP_016292663.1 & 72/GAC76671.1 \\
\hline MW602838 & 692 & 59/CBQ69373.1 & 57/XP_016294204.1 & 58/XP_014653303.1 \\
\hline MW602839 & 628 & 57/CBQ72101.1 & 57/XP_016292807.1 & 60/XP_014658379.1 \\
\hline MW602840 & 697 & 66/CBQ73979.1 & 67/XP_016294579.1 & 66/GAC73024.1 \\
\hline MW602841 & 623 & 52/SJX63798.1 & 56/XP_016294560.1 & 55/XP_014656193.1 \\
\hline MW602842 & 818 & 62/SJX60288.1 & 64/XP_016294861.1 & 62/GAC73485.1 \\
\hline MW602843 & 882 & 58/CBQ68442.1 & 58/XP_016293046.1 & 58/XP_014655816.1 \\
\hline MW602844 & 476 & 55/CBQ69840.1 & 54/XP_016293731.1 & 54/XP_014655209.1 \\
\hline MW602845 & 511 & 66/SJX61686.1 & 68/XP_016292559.1 & 67/GAC76557.1 \\
\hline MW602846 & 463 & 64/CBQ67637.1 & 64/XP_016294848.1 & 61/XP_014659737.1 \\
\hline MW602847 & 535 & 35/CBQ67637.1 & 37/XP_016291715.1 & 35/XP_014659737.1 \\
\hline MW602848 & 632 & 54/SJX66403.1 & 51/XP_016292381.1 & 54/XP_014654407.1 \\
\hline MW602849 & 517 & 55/SJX64821.1 & 55/XP_016294313.1 & 59/XP_014655490.1 \\
\hline MW602850 & 628 & 65/SJX60939.1 & 65/XP_016295177.1 & 69/GAC72911.1 \\
\hline MW602851 & 409 & 69/CBQ73807.1 & ND/ND & 67/XP_014656356.1 \\
\hline MW602852 & 259 & 60/CBQ67856.1 & 66/XP_016295047.1 & 62/XP_014659518.1 \\
\hline MW602853 & 365 & 56/SJX64569.1 & 56/XP_016293526.1 & 57/XP_014655410.1 \\
\hline MW602854 & 396 & 67/SJX62056.1 & 68/XP_016292880.1 & 68/GAC76931.1 \\
\hline MW602855 & 664 & ND/ND & 55/XP_016295198.1 & 52/GAC72934.1 \\
\hline MW602856 & 376 & 57/CBQ72875.1 & ND/ND & 58/XP_014657530.1 \\
\hline MW602857 & 462 & 24/SJX62708.1 & $\mathrm{ND} / \mathrm{ND}$ & 26/XP_014657530.1 \\
\hline MW602858 & 358 & 69/CBQ72875.1 & ND/ND & 70/XP_014657530.1 \\
\hline MW602859 & 315 & ND/ND & ND/ND & 26/XP_014654444.1 \\
\hline MW602861 & 388 & ND/ND & ND/ND & ND/ND \\
\hline MW602862 & 685 & 47/SJX65314.1 & ND/ND & 50/XP_014655028.1 \\
\hline MW602860 & 355 & ND/ND & ND/ND & $\mathrm{ND} / \mathrm{ND}$ \\
\hline MW602864 & 340 & 48/CBQ73812.1 & 26/XP_016292247.1 & 49/XP_014656336.1 \\
\hline MW602865 & 300 & 32/SJX60889.1 & ND/ND & 48/GAC73181.1 \\
\hline MW602866 & 406 & 62/SJX61842.1 & ND/ND & 62/SPO44190.1 \\
\hline MW602867 & 388 & 67/CBQ69308.1 & 68/XP_016294261.1 & 68/GAC71400.1 \\
\hline
\end{tabular}


N. W. Soria et al.

\section{Continued}

\begin{tabular}{|c|c|c|c|c|}
\hline MW602868 & 317 & 49/CBQ70225.1 & 48/XP_016295216.1 & 52/XP_014658559.1 \\
\hline MW602869 & 311 & 55/SJX64888.1 & 64/XP_016294378.1 & 64/XP_014655560.1 \\
\hline MW602870 & 594 & ND/ND & 37/XP_016291482.1 & 29/XP_014657903.1 \\
\hline MW602871 & 1069 & 73/CBQ69224.1 & 73/XP_016294356.1 & 73/XP_014655537.1 \\
\hline MW602872 & 880 & 60/CBQ72182.1 & 60/XP_016292886.1 & 61/GAC76924.1 \\
\hline MW602873 & 787 & 62/CBQ72762.1 & 63/XP_016289797.1 & 64/GAC72061.1 \\
\hline MW602874 & 547 & 60/CBQ71096.1 & 65/XP_016290857.1 & 60/XP_014657670.1 \\
\hline
\end{tabular}

ND: no data. 